\title{
THE UTILIZATION OF LOOSE PARTS MEDIA IN STEAM LEARNING FOR EARLY CHILDHOOD
}

\author{
Siti Wahyuningsih ${ }^{1)}$, Adriani Rahma Pudyaningtyas ${ }^{2)}$, Novita Eka Nurjanah ${ }^{3)}$, Nurul \\ Kusuma Dewi ${ }^{4)}$, Ruli Hafidah ${ }^{5)}$, Muhammad Munif Syamsuddin'), Vera Sholeha ${ }^{7}$ \\ PG-PAUD, Universitas Sebelas Maret \\ siti_w@staff.uns.ac.id
}

\begin{abstract}
STEAM-based learning (Science, Technology, Engineering, Arts, and Mathematics) has begun to be developed a lot recently. This learning is considered able to answer the challenges of the times to be able to develop learning in the 21st century. STEAM is not only developed for secondary to tertiary education but is also developed for learning in early childhood. The challenges for developing STEAM-based learning are not small. The teacher considers that to provide learning about technology, for example, one must use sophisticated computer-based learning media, so it requires expensive costs. Also, science and engineering learning has not been developed much in kindergarten (TK) learning because it is considered a difficult concept to understand and requires high costs for the learning media. Learning media for early childhood is diverse and does not have to all buy new materials at a high cost. Likewise with learning media that can be used to develop STEAM-based learning. Teachers can make use of items or materials that are easily available, such as rocks, tree branches, seeds, used bottle caps, dry leaves, clothespins, etc. These removable materials are called loose parts. Loose parts are loose objects that can be moved, manipulated, and how to use them is determined by the child. These removable materials as learning media can make children think creatively and imaginatively. Loose parts can also be used as media in STEAM learning.
\end{abstract}

Keywords: loose parts, STEAM, media

\section{PEMANFAATAN MEDIA LOOSE PARTS DALAM PEMBELAJARAN STEAM UNTUK ANAK USIA DINI}

\begin{abstract}
Abstrak: Pembelajaran berbasis STEAM (Science, Technology, Engineering, Arts, dan Mathematics) mulai banyak dikembangkan akhir-akhir ini. Pembelajaran ini dinilai mampu menjawab tantangan zaman untuk dapat mengembangkan pembelajaran di abad 21. STEAM tidak hanya dikembangkan untuk pendidikan menengah sampai perguruan tinggi tetapi juga dikembangkan untuk pembelajaran pada anak usia dini. Tantangan untuk mengembangkan pembelajaran berbasis STEAM tidak sedikit. Guru memandang bahwa untuk memberikan pembelajaran tentang teknologi misalnya harus menggunakan media pembelajaran berbasis komputer yang canggih, sehingga membutuhkan biaya yang mahal. Selain itu, pembelajaran sains dan teknik belum banyak dikembangkan pada pembelajaran Taman Kanak-Kanak (TK) karena dianggap konsep yang sulit dipahami dan membutuhkan biaya yang tinggi untuk media pembelajarannya. Media pembelajaran untuk anak usia dini beragam dan tidak harus semua membeli bahan baru dengan biaya tinggi. Begitu pula dengan media pembelajaran yang dapat digunakan untuk mengembangkan pembelajaran berbasis STEAM. Guru dapat memanfaatkan barang atau bahan yang mudah didapat, seperti batu, ranting pohon, biji-bijian, tutup botol bekas, daun kering, jepitan, dan lain-lain. Bahan yang dapat dilepas ini disebut dengan loose parts. Bagian lepas adalah benda lepas yang dapat dipindahkan, dimanipulasi, dan cara penggunaannya ditentukan oleh anak. Bahan lepasan ini sebagai media pembelajaran dapat membuat anak berpikir kreatif dan imajinatif. Bagian yang lepas juga dapat digunakan sebagai media dalam pembelajaran STEAM.
\end{abstract}

Keywords: loose parts, STEAM, media

\section{PENDAHULUAN}

Pendidikan di abad 21 yang telah memasuki era disrupsi dan era revolusi industri 4.0 dituntut untuk terus berinovasi. Pendidikan Anak Usia Dini (PAUD) sebagai salah satu lembaga pendidikan dasar, harus bersiap untuk menjawab tantangan perkembangan zaman. PAUD dituntut pula untuk melakukan perubahan baik dalam kurikulum maupun pembelajarannya. Anak-anak yang belajar di PAUD harus dibekali dengan berbagai macam keterampilan (hard skills dan soft skills) untuk dapat beradaptasi dengan perubahan yang terjadi di sekelilingnya. Keterampilan yang perlu diajarkan pada 
anak yaitu keterampilan berpikir kritis, berpikir kreatif (kreativitas), kerja sama, dan komunikasi selain tentunya anak belajar mengenai pengetahuan (pengetahuan fisik, logika matematika, dan sosial). Keterampilan- keterampilan tersebut harus dilakukan secara terintegrasi dalam proses pembelajaran.

Pembelajaran STEAM (Science,

Technology, Engineering, Arts, and Mathematics) dianggap sebagai pembelajaran yang mampu untuk mengintegrasikan keterampilanketerampilan (hard skills maupun soft skills) yang diperlukan oleh anak. STEM (Science, Technology, Engineering, and Mathematics) mendorong anak untuk membangun pengetahuan tentang dunia di sekelilingnya melalui kegiatan mengamati, meyelidiki, dan menanya (Akturk, Demircon, Senyurt, \& Cetin, 2017) [1]. STEM dianggap sebagai pembelajaran yang berharga dan bermakna bagi anak. Guru dan pendidik meyakini bahwa dengan pembelajaran STEM siswa akan lebih aktif dan mampu berpikir kritis dalam membangun pengetahuannya (Tippet \& Milford, 2017) [2]. Penambahan "Arts" (sehingga disingkat STEAM) akan memberikan kesempatan anak dalam menggambarkan konsep STEM dengan cara-cara yang kreatif dan imajinatif (Siantajani, 2018) [3].

STEAM digunakan untuk fokus pada pemahaman tentang sifat terintegrasi dari disiplin sains, teknologi, teknik, seni, dan matematika serta pentingnya mereka dalam keberhasilan akademik jangka panjang anak- anak, kesejahteraan ekonomi (Quigley \& Herro, 2016) [4], dan pengembangan masyarakat (Han et al., 2016) [5]. Pendidikan STEM mencakup nilai dari prasekolah hingga tingkat pascadoktoral dan pengaturan pembelajaran formal (misal ruang kelas) dan pendidikan informal (misal Program afterschool) (Gonzalez \& Kuenzi, 2012) [6]. Sebagai gambaran, pendidikan STEM telah diakui di AS sebagai reformasi pendidikan yang penting dan digambarkan sebagai pendekatan instruksional untuk mempersiapkan anak-anak menghadapi ekonomi global abad ini (Yakman \& Lee, 2012) [7].

Salah satu bentuk media pembelajaran yang diterapkan dalam pembelajaran STEAM untuk anak usia dini adalah loose parts. Loose parts merupakan bahan-bahan terbuka, terpisah, dapat dijadikan satu kembali, dibawa, digabungkan, dijajar, dipindahkan, dan digunakan sendiri ataupun digabungkan dengan bahan-bahan lain (benda alam ataupun sintetis). Loose parts dapat digunakan sebagai bahan pembelajaran STEAM karena sesuai dengan karakteristik anak, dapat diadaptasi dan dimanipulasi dalam banyak cara, mendukung kreativitas dan imajinasi anak, serta mampu untuk mengembangkan ide anak (Siantajani, 2018) [3].

Loose parts membantu anak untuk mengambil resiko, mengeksplorasi dan menyelidiki sambil terlibat aktif, sensorik, kolaboratif, dan bermain drama. Haughey \& Hill 2017 [8] menyatakan bahwa loose part merupakan kumpulan benda alam atau benda buatan yang dapat digunakan untuk memancing ide dalam permainan anak. Benda-benda ini bersifat terbuka sehingga mendukung perkembangan anak untuk berkarya. Proses penggunaan loose parts mendorong anak untuk melakukan pengamatan dan penelitian akan bendabenda yang akan digunakan.

Kiewra dan Vaselek (2016) [9] berpendapat bahwa loose parts merupakan sebuah benda potongan yang bebas dimainkan dan tidak dapat diprediksi akan menjadi apa. Loose parts mendukung perkembangan pola pikir anak yang berbeda-beda dan unik. Hal ini dikarenakan loose part tidak memiliki aturan terikat untuk digunakan, kemungkinan yang dimiliki tidak terbatas dan dapat terus dieksplorasi anak. Bahan-bahan terbuka yang dapat ditemukan dimana saja dapat memberikan stimulus bagi perkembangan 
anak untuk mengenali potensi berpikirnya. Anak dapat dengan bebas menentukan akan menjadi apa benda tersebut dan benda mana yang dipilihnya untuk dimainkan.

Realita di lapangan, pengetahuan pendidik PAUD di Indonesia mengenai pembelajaran STEAM ini sangat terbatas. Hal ini didukung berdasarkan hasil wawancara yang dilakukan kepada beberapa guru TK khususnya di Gugus Melati, Kecamatan Colomadu, Kabupaten Karanganyar belum mengetahui apa itu STEAM, media yang digunakan dalam pembelajaran STEAM berupa loose parts apalagi menerapkan di dalam pembelajaran untuk anak usia dini. Ketidaktahuan pendidik PAUD tentang pembelajaran STEAM dengan media loose parts ini menjadi kendala dalam mendukung pendidikan abad 21 yang harus mengikuti perkembangan zaman. Hal ini juga menghambat pengembangan berbagai macam keterampilan nak usia dini untuk dapat beradaptasi dengan perubahan yang terjadi di sekelilingnya.

$$
\text { Pendidik PAUD selama }
$$

pembelajaran cenderung hanya menggunakan satu jenis media pembelajaran, yiatu Lembar Kerja Anak (LKA). Anak hanya duduk dalam waktu tertentu. Hal ini berarti anak tidak diajak untuk melakukan kegiatan yang menstimulasi kreativitas, komunikasi, kolaborasi, dan berpikir kritis yang seharusnya hal tersebut distimulasi pada pendidikan abad 21 ini. Dengan kata lain, anak tidak diberikan pengalaman dalam melakukan penyelidikan, memecahkan masalah, dan bereksplorasi. Kegiatan ini tidak mendukung perkembangan anak untuk berkarya sehingga anak perkembangan anak tidak optimal. Berdasarkan permasalahan-permasalahan yang dihadapi para guru PAUD khususnya di Gugus Melati, Kecamatan Colomadu, Kabupaten Karanganyar, pada pengabdian kali ini akan dikembangkan pemanfaatan media loose parts dalam pembelajaran STEAM untuk anak usia dini.

\section{METODE PENELITIAN}

Kegiatan pengabdian dilaksanakan selama tiga hari pada tanggal 6 s.d 8 September 2020. Pengabdian dilaksanakan di kampus Universitas Sebelas Maret dengan peserta guru-guru TK Gugus Melati, Kecamatan Colomadu, Kabupaten Karanganyar berjumlah 10 orang guru.

Metode yang digunakan dalam pengabdian ini adalah dengan menggunakan pelatihan. Ada tiga cakupan materi yang disajikan dalam pelatihan, yaitu pembelajaran berbasis STEAM, media pembelajaran loose parts, dan penyusunan perangkat pembelajaran berbasis STEAM dengan media loose parts.

Pada materi pertama, guru-guru disajikan wawasan mengenai pembelajaran abad 21 yang mengkhusus pada pembelajaran berbasis STEAM. Dimulai dari sejarah munculnya STEM sampai dengan perkembangannya saat ini yang memasukkan unsur "arts", sehingga menjadi STEAM. Pembelajaran STEAM yang diberikan adalah pembelajaran khususnya untuk anak usia dini.

Materi yang kedua adalah tentang media pembelajaran. Cakupan materi meliputi pengertian, fungsi, serta cara memilih media pembelajaran, dan ditutup dengan jenis-jenis media pembelajaran yang salah satunya mengupas mengenani loose parts. Guru-guru diberikan wawasan mengenai pengertian, macam-macam, serta penggunaan loose parts dalam pembelajaran.

Pelatihan ditutup dengan pendampingan pembuatan perangkat pembelajaran STEAM dengan menggunakan loose parts. Pembuatan perangkat pembelajaran dicobakan untuk beberapa tema yang berbeda. Setelah membuat perangkat pembelajaran, guruguru mencoba membawakan perangkat pembelajaran tersebut dalam sebuah microteaching. 


\section{HASIL DAN PEMBAHASAN}

Hasil dari pelatihan yang telah dilaksanakan dapat diamati dari perubahan yang dilakukan oleh guru. Kegiatan monitoring dilaksanakan setelah guru mengikuti pelatihan. Monitoring mencakup implementasi pembelajaran STEAM dan pemanfaatan media loose parts.

$$
\text { Pada awal melakukan }
$$

implementasi, pembelajaran berbasis STEAM masih belum terintegrasi dengan baik. Pembelajaran STEAM masih terpisah-pisah dan berdiri sendiri. Namun, setelah 2 kali dilakukan proses refleksi bersama dengan rekan sejawat maupun rekan pengabdi, maka perubahanperubahan positif berhasil dilakukan. Pembelajaran STEAM semakin terlihat bentuknya dan sudah menyatu dengan baik dalam pelaksanaan pembelajaran, yang tentu saja diikuti dengan perubahan yang signifikan pada perangkat pembelajarannya.

Perubahan yang positif juga dilihat dalam pemanfaatan media loose parts. Media yang mudah didapat, membantu guru untuk bisa mendapatkan media pembelajaran yang murah. Penggunaan media loose parts pada awalnya yang mengalami kesulitan justru anak-anak peserta didik. Anak-anak belum terbiasa dihadapkan pada benda-benda lepasan yang harus disusun sedemikian rupa sehingga menjadi benda yang bermaknsa sesuai dengan keinginan anak sendiri, sesuai dengan daya imajinasi dan kreativitas anak. Anak-anak terlihat takut melakukan kesalahan dalam menggunakan media loose parts tersebut. Namun, setelah beberapa kali disajikan media loose parts dalam kegiatan pembelajarannya, maka anak-anak mulai terbiasa dan semakin percaya diri membuat beraneka ragam hasil karya dari bahan-bahan yang disediakan.

Terakhir, setelah fasih menggunakan pembelajaran STEAM dan media loose parts, guru-guru mencoba menggabungkan kedua konsep tersebut menjadi sebuah perangkat pembelajaran yang utuh. Perangkat pembelajaran yang memuat STEAM dengan memanfaatkan media loose parts. Tidak terdapat kendala dalam pengorganisasian kedua konsep tersebut, karena guru telah siap secara matang baik konsep teori maupun pengalaman setelah melakukan beberapa kali uji coba. Begitu pula dengan anak-anak yang sudah terbiasa dengan pembelajaran STEAM dan media loose parts.

Guru-guru secara tidak langsung melalui kegiatan ini, telah berupaya untuk melakukan adaptasi terhadap perubahan zaman. Bergerak menuju ke pembelajaran abad 21. Guru yang inovatif dan kreatif, akan mendorong peserta didik untuk dapat pula mengembangkan keterampilanketerampilan yang diperlukan di era disrupsi ini baik hard skills maupun soft skills.

\section{SIMPULAN}

Perkembangan zaman menuntut setiap manusia untuk selalu berbenah mengikuti perubahan dalam semua aspek kehidupan, tidak terkecuali. Perubahan zaman juga berdampak pada perkembangan dalam bidang pendidikan. Peserta didik dan guru dituntut untuk semakin kritis, inovatif, dan kreatif. Pembelajaran STEAM merupakan salah satu pembelajaran yang saat ini dinilai mampu untuk menjawab tantangan zaman. Pemanfaatan media juga dituntut untuk dapat mengembangkan daya kreativitas peserta didik. Salah satu media yang bisa dimanfaatkan adalah loose parts.

Pelatihan tidak hanya berhenti sampai di sini, akan lebih baik jika dapat dipadukan dengan pendekatan, strategi, metode, dan teknik pembelajaran lain yang inovatif yang sesuai dengan perkembangan zaman.

\section{DAFTAR PUSTAKA}

[1] Ata Aktürk, A., Demircan, H. özlen, Şenyurt, E., \& Çetin, M. (2017). Turkish early childhood education curriculum from the perspective of STEM education: A document 
analysis. Journal of Turkish Science Education, 14(4), 16-34. https://doi.org/10.12973/tused.102 $10 \mathrm{a}$

[2] Tippett, C. D., \& Milford, T. M. (2017). Findings from a Pre-kindergarten Classroom: Making the Case for STEM in Early Childhood Education. International Journal of Science and Mathematics Education, 15, 67-86. https://doi.org/10.1007/s10763$\underline{017-9812-8}$

[3] Siantajani, Y. (2018). Playing with loose parts. Modul (tidak diterbitkan).

[4] Herro, D. and Quigley, C. (2016), Innovating with STEAM in middle school classrooms: remixing education, On the Horizon, Vol. 24 No. 3, pp. 190-204. https://doi.org/10.1108/OTH-032016-0008

[5] Han, S., Rosli, R., Capraro, M. M., \& Capraro, R. M. (2016). The effect of Science, technology, engineering and mathematics (STEM) project based learning (PBL) on students' Achievement in four mathematics topics. Journal of Turkish Science Education, 13(Specialissue), 3-30. https://doi.org/10.12973/tused.101 $\underline{68 \mathrm{a}}$

[6] González, H.B., \& Kuenzi, J.J. (2012). Science, Technology, Engineering, and Mathematics (STEM) Education: A Primer [August 1, 2012].

[7] Yakman, G., \& Lee, H. (2012). Exploring the Exemplary STEAM Education in the US as a Practical Educational Framework for Korea.
Journal of Korea Association Science Education, 32(6), 10721086.

[8] Haughey, S., \& Hill, N. (2017). A Start Up Guide Loose Parts : A Start-Up Guide. 1-27. www.fairydustteaching.com

[9] Kiewra, C., \& Veselack, E. (2016). Playing with Nature: Supporting Preschoolers' Creativity in Natural Outdoor Classrooms. International Journal of Early Childhood Environmental Education, 4(1), 70-95. 